2. To: (Ficceiving Organization) WRAP 1

5. Proj./Frog./Dept./Div.:

3. From: (Originating Organization) WRAP 1

6. Design Authority/ Design Agent/Cog. Engr.:

W026/Solid Waste

TL Watson

No.:

Construction

TL Watson

N/A

7. Purchase Order No.:

$N / A$

8. Originator Remarks:

For release

9. Equip./Component No.:

$N / A$

10, Systeni/Bldg./Facility:

$N / A$

11. Receiver Remarks: 11A. Design Baseline Document? [] Yes [X] No

12. Major Assm. Dwg. No.:

$N / A$

13. Permit/Permit Application No.: $N / A$

14. Required Response Date: $N / A$

\begin{tabular}{|c|c|c|c|c|c|c|c|c|}
\hline 15. & & DAIA & TRANSMITIED & & (F) & (G) & (H) & (1) \\
\hline $\begin{array}{l}|A| \\
\text { Item } \\
\text { No. }\end{array}$ & (B) Document/Drawing No. & $\begin{array}{l}\text { (C) } \\
\text { Sheot } \\
\text { No. }\end{array}$ & $\begin{array}{l}\text { (D) } \\
\text { Rev. } \\
\text { No. }\end{array}$ & $\begin{array}{l}\text { (E) Title or Description of Data } \\
\text { Transmitted }\end{array}$ & $\begin{array}{l}\text { Approval } \\
\text { Desig. } \\
\text { nator }\end{array}$ & $\begin{array}{l}\text { Reason } \\
\text { for } \\
\text { Trans- } \\
\text { mittal }\end{array}$ & $\begin{array}{l}\text { Origi- } \\
\text { nator } \\
\text { Dispo- } \\
\text { sition }\end{array}$ & $\begin{array}{l}\text { Receiv- } \\
\text { or } \\
\text { Dispo- } \\
\text { sition }\end{array}$ \\
\hline 1 & HNF-SD-W026-ATP-018 & & 0 & $\begin{array}{l}\text { Box Non-Destructive } \\
\text { Examination Systers Plan }\end{array}$ & $a$ & 2 & 1 & \\
\hline 2 & WHL-SD-W026-ATR-018 & & 0 & $\begin{array}{l}\text { Box Non-Destruct ive } \\
\text { Examination System Report }\end{array}$ & Q & 2 & 1 & \\
\hline & & & & & & & & \\
\hline & & & & & & & & \\
\hline & & & & & & & & \\
\hline
\end{tabular}

\begin{tabular}{|c|c|c|c|c|}
\hline \multicolumn{5}{|l|}{16.} \\
\hline Approval Lesignator (F) & & Reason for Transmittal (G) & Dispo & $\operatorname{ion}(H) \&(I)$ \\
\hline $\begin{array}{l}\text { E. S, } 0, D \text { or N/A } \\
\text { (see WH+C-CM-3-5, } \\
\text { Sec. } 12,7 \text { ) }\end{array}$ & $\begin{array}{l}\text { 1. Approval } \\
\text { 2. Release } \\
\text { 3. Information }\end{array}$ & $\begin{array}{l}\text { 4. Reviow } \\
\text { 5. Post-Review } \\
\text { 6. Dist. (Receipt Acknow. Required) }\end{array}$ & $\begin{array}{l}\text { 1. Approved } \\
\text { 2. Approved w/comment } \\
\text { 3. Disapproved w/comment }\end{array}$ & $\begin{array}{l}\text { 4. Reviewed no/comment } \\
\text { 5. Revlewed w/comment } \\
\text { 6. Receipt acknowledged }\end{array}$ \\
\hline
\end{tabular}

\begin{tabular}{|c|c|c|c|c|c|c|c|}
\hline \multicolumn{8}{|c|}{$\begin{array}{l}\text { 17. SIGNATURE/DISTRIBUTION } \\
\text { (See Approval Designator for required signatures) }\end{array}$} \\
\hline $\begin{array}{l}\text { (G) } \\
\text { Rea- } \\
\text { son }\end{array}$ & $\begin{array}{l}\text { (HH } \\
\text { Disp }\end{array}$ & \multicolumn{2}{|c|}{ 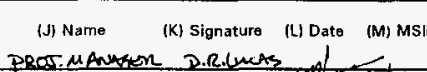 } & $\begin{array}{c}(G) \\
\text { Rea- } \\
\text { son }\end{array}$ & $\begin{array}{l}\text { (H) } \\
\text { Disp. }\end{array}$ & (J) Narne & $\begin{array}{lll}\text { (K) Signature (L) Date (M) MSIN } & \text { (M) }\end{array}$ \\
\hline 1 & 1 & \multicolumn{4}{|c|}{ 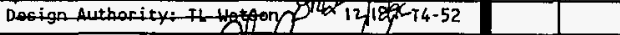 } & & \\
\hline 1 & 1 & \multicolumn{4}{|c|}{ Proj. Engr.: JB Paynd fol hepe $12 / \delta 46$ T4-02 } & & \\
\hline 1 & 1 & \multicolumn{4}{|c|}{ Cog.Eng.: KL Humphryels } & & \\
\hline 1 & 1 & \multicolumn{4}{|c|}{ Cog. Mgr -: RJ Bottenus $/ 2 / 20$} & & \\
\hline 1 & 1 & \multicolumn{4}{|c|}{ 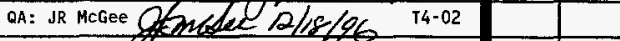 } & & \\
\hline & & \multicolumn{4}{|c|}{ Safety } & & \\
\hline & & \multicolumn{4}{|l|}{ Env. } & & \\
\hline \multicolumn{2}{|l|}{18.} & 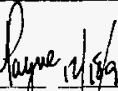 & 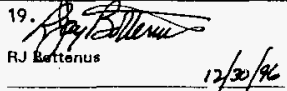 & 20. 90 & & $130 / 96$ & \multirow{2}{*}{$\begin{array}{l}\text { 21. DOE APPROVAL (if required) } \\
\text { Ctrl. NO. } \\
\text { [] Approved } \\
\text { [] Approved w/comments } \\
\text { [] Disapproved w/comments }\end{array}$} \\
\hline \multicolumn{2}{|c|}{$\begin{array}{l}\text { Signature of } E \\
\text { Originator }\end{array}$} & Date & $\begin{array}{l}\text { Authorized Representative } \text { Dat6 } \\
\text { for Receiving Organization }\end{array}$ & $\begin{array}{l}\text { Dosign Auth } \\
\text { Cognizant M }\end{array}$ & ityl & Date & \\
\hline
\end{tabular}


THIS PAGE INTENTIONALLY LEFT BLANK 


\section{W-026, Acceptance Test Report Box Non-Destructive Examination System (Submittal \# 046.2) 5368}

TL Watson

Westinghouse Hanford, Rich1and, WA 99352

U.S. Department of Energy Contract DE-AC06-87RL10930

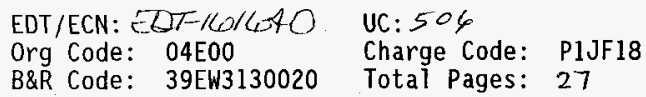

Key Words: ATR, WRAP 1, NDE, X-Ray

Abstract: This test was satisfactoryily performed by $V$. J.

Technologies, Inc., with witnesses from WRAP 1 Engineering, ICF-KEH Acceptance Inspectors, and WHC NDE Radiographers.

TRADEMARK DISCLAIMER. Reference herein to any specific commercial product, process, or service by trade name, trademark, manufacturer, or otherwise, does not necessarily constitute or imply its endorsement, recommendation, or favoring by the United States Government or any agency thereof or its contractors or subcontractors.

Printed in the United States of America. To obtain copies of this document, contact: WHC/BCS Document Control Services, P.O. Box 1970, Mailstop H6-08, Richland WA 99352, Phone (509) 372-2420; Fax (509) 376-4989.
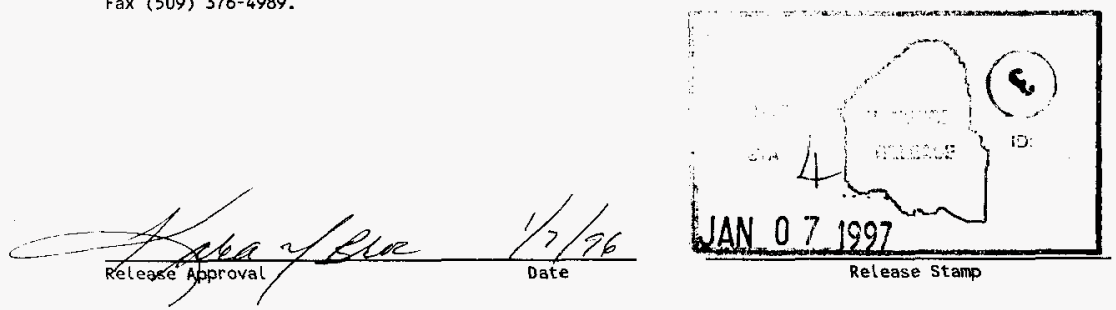

Approved for Public Release 
THIS PAGE INTENTIONALLY LEFT BLANK 


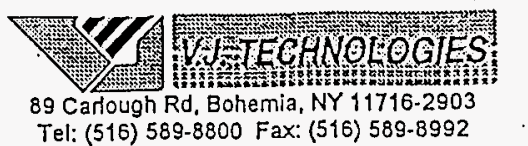

(516) 589-8800 Fax: (516) 589-8992

\section{ACCEPTANCE TEST PROCEDURE}

WASTE- RECEIVING AND PROCESSING FACILITY, MODULE 1

BOX NON-DESTRUCTIVE EXAMINATION SYSTEM

KEH-5368(W-026) 
THIS PAGE INTENTIONALLY

LEFT BLANK 


\section{EXECUTION AND TEST APPROVAL SHEET}

\section{EXECUTORS}

$\frac{(\text { SEE ATTACHED FAX })}{\text { Direztorlorganization }}$
S.D. EWING/X.J.T.
(SEE ATTACHEO FAX)
Recorder/Organization
S.D. EN

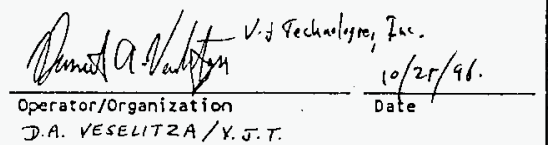

\section{HITHESSES}

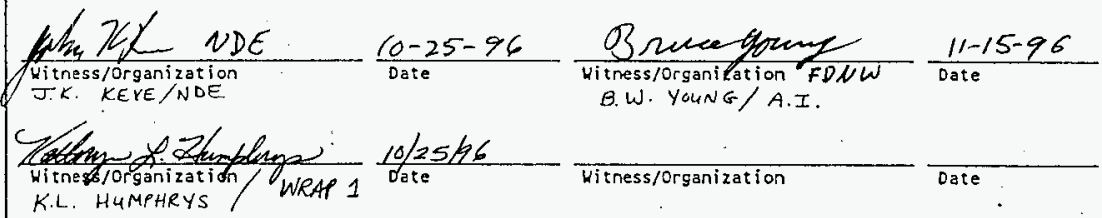

\section{TEST APPROVAL AND ACCEPTANCE}

Westinghouse Hanford Company

Hithot-exceptions:

With exceptions resolved: $X$

With exeptions outstanding:

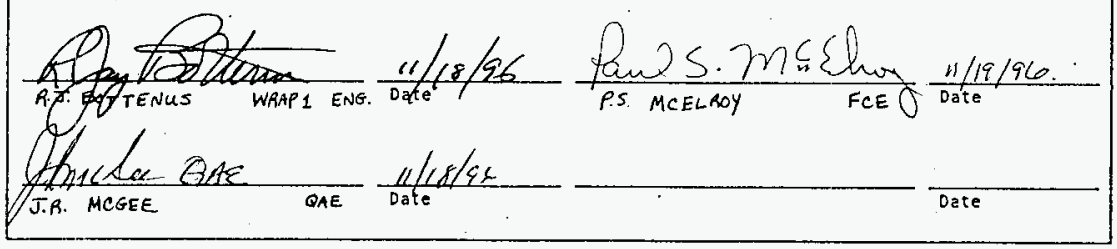


95 10/2B 13:00 FAX 5107531176

Ewing Tt HNF-SD-W026-ATR-018, Rev. 0 Page 3

10/28/96 MON 11:05 FAX 15093733891

TRAP COYPLEX

Doos

KEH-5368(HO26) REY. O

EXECUTION AND TEST APPROYAL SHEET

EXECUTORS

EXECUTORS

$\frac{1929}{\text { oxre }} 96$

oxpraterororsanization

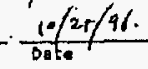

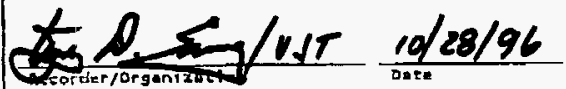

HITKESSES

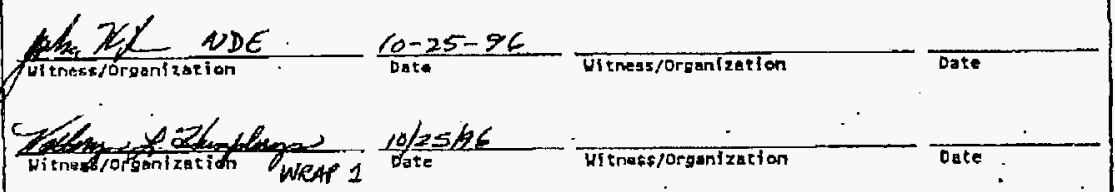

TEST APPROVAL AND ACCEPTANCE

yestinghous Hanford company.

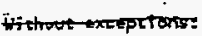

With exceptions resolved: $x$

ulth-anding:-

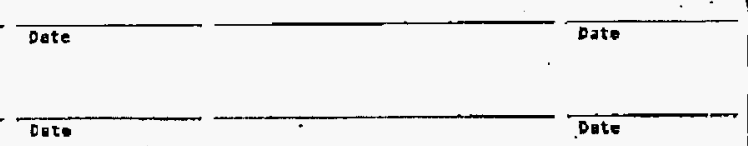

11

I $9610 / 9911 \cdot n R$

TY/LY NA n?חO

D $\cap \cap x$ 
KEH-5368(K026) REV. 0

TABLE OF CONTENTS

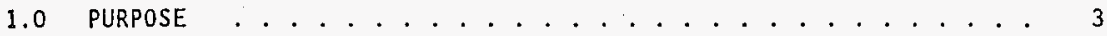

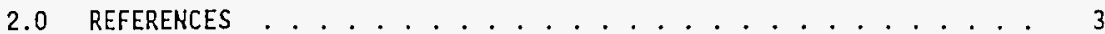

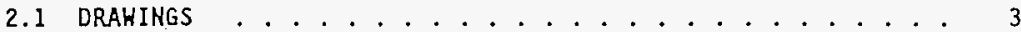

2.2 SPECIFICATIONS ...................... 3

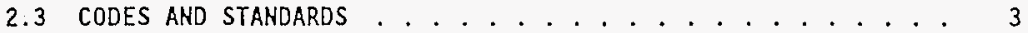

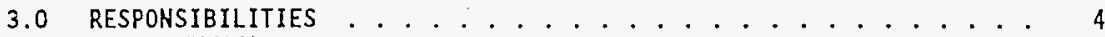

3.1 GENERAL . . . . . . . . . .......... . . . 4

3.2 TEST DIRECTOR . . . . . . . . . . . . . . . . . 4

3.3 WITNESSES . . . . . . . . . . . . . . . . 5

3.4 RECORDER . . . . . . . . . . . . . . . . . 5

3.5 TEST OPERATOR $\ldots \ldots \ldots \ldots$

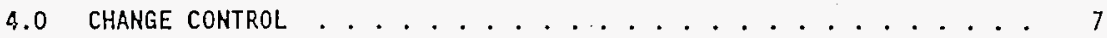

5.0 EXECUTION . . . . . . . . . . . . . . . . 7

5.1 OCCUPATIONAL SAFETY AND HEALTH ........... 7

5.2 PERFORMANCE ...................... 7

6.0 EXCEPTIONS . . . . . . . . . . . . . . . . . . 8

6.1 GENERAL . . . . . . . . . . . . . . . . . 8

6.2 RECORDING . . . . . . . . . . . 8

6.3 RETEST/RESOLUTION . . . . . . . . . . . . 8

6.4 APPROVAL AND ACCEPTANCE . . . . . . . . . . . . 8

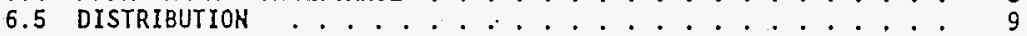

7.0 PREREQUISITES AND EQUIPMENT REQUIRED ............... . . 9

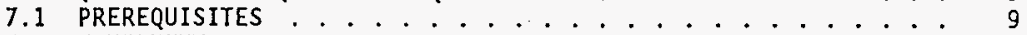

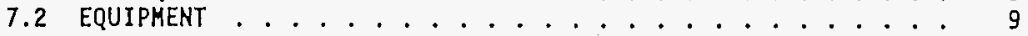

8.0 PLANT CONTROL SYSTEM (PCS) INTERFACE ............. . . . 9

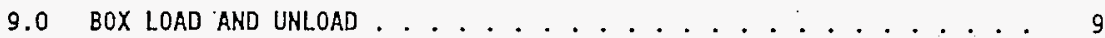

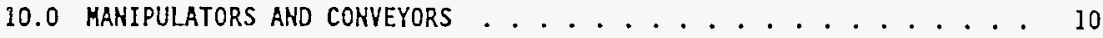

11.0 Image chain . . . . . . . . . . . . . 10

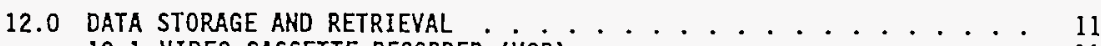

12.1 VIDEO CASSETTE RECORDER $($ VCR $) \ldots \ldots . . . \ldots 11$

12.3 PRINTER . . . . . . . . . . . . . . 11

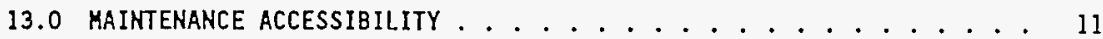




\section{KEH-5368(H026) REV. 0}

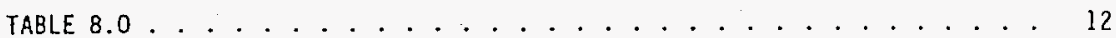

TABLE $9.0 \ldots \ldots \ldots \ldots \ldots$

EXCEPTION SHEET ............................. 14 
KEH-5358(HO26) REV. 0

\section{WASTE RECEIVING AND PROCESSING FACILITY, KODULE I BOX NON-DESTRUCTIVE EXAMINATION SYSTEM ACCEPTANCE TEST PROCEDURE}

\section{I.0 PURPOSE}

The Waste Receiving and Processing Facility, Module 1 (WRAP 1) Box NonDestructive Examination (NDE). System is designed to use $x$-ray technology to safely examine boxes containing radioactive and mixed waste. It is designed to meet the requirements of the Code of Federal Regulations, the Washington Administrative Code, and the American National Standards Institute.

This Acceptance Test Procedure (ATP) has been prepared to demonstrate that the WRAP. 1 BOX NDE System will function as intended by the Integrated Construction Forces Kaiser Engineers Hanford Company (ICF KH) procurement requisition KEH5368. This document is prepared in compliance with Section 13533 and Appendix $A$ of the $W-026$ Construction Specification.

The test results will be issued as an Acceptance Test Report (ATR) after all testing is complete. The test will be performed in WRAP 1 .

\subsection{REFERENCES}

\subsection{DRAHINGS}

"Relay Module," J2348, sheet 2

"PCS Inputs," J2348, sheet 3

\subsection{SPECIFICATIONS}

Contract Number $\mathrm{V}-\mathrm{H}-026-\mathrm{C2}$, WRAP 1 NDE Systems

Procurement Requisition KEH-5368, WRAP I NDE Systems

Construction Specification Section 13533, Box Non-Destructive Examination System.

\subsection{CODES AND STANDARDS}

Code of Federal Regulations (CFR) - 21 CFR 1020.40, Radiation Protection, Industrial Radiography

American National Standards Institute (ANSI) - ANSI N43.3, 1993, General Safety Standard - Installations using Non-Medical X-Ray and Sealed Gamma-Ray Sources, Energies up to $10 \mathrm{Hev}$.

Washington Administrative Code (WAC) - WAC, 1990, Chapter 246-243, Radiation Protection, Industrial Radiography 
KEH-5368(H026) REV. O

\subsection{RESPONSIBILITIES}

The test shall be performed by a representative from ICF KH who is technically qualified and knowledgeable of the safety requirements associated with the testing.

Each company or organization participating in the conduct of this test will designate personnel to assume the responsibilities and duties assigned herein. The names shall be provided to the recorder for listing on the recorder's copy of the test execution sheet prior to the performance of any part of the test.

\subsection{GENERAL}

Each company or organization participating in this ATP will designate personnel to assume the responsibilities and duties as defined herein for their respective roles. The designees shall become familiar with this ATP and the systems involved to the extent that they can perform their assigned duties.

\subsection{TEST DIRECTOR}

3.2.1 Coordinates testing with ICF KH and directs acceptance testing.

3.2.2 Acts as liaison between the participants in acceptance testing.

3.2.3 Distributes the approved testing schedule before start of testing.

3.2.4 Schedules and conducts a pretest kickoff meeting with test participants before start of testing when necessary.

3.2.5 Notifies the persons performing and witnessing the test 2 days before the start of testing.

3.2.6 Schedules a dry run when necessary.

3.2.7 Notifies concerned parties when a change is made in the testing schedule.

3.2.8 Takes necessary action to clear exceptions to the test.

3.2.9 Confirms that field testing and inspection of the system or portion of the system to be tested has been completed.

3.2.10 Stops any test which, in his/her judgement, may cause damage to the system until the problem has been resolved. 
KEH-5368(W026) REV. 0

3.2.11 After verifying there is no adverse impact, may alter the sequence in which systems or subsystems are tested.

3.2.12 Ensures that required environmental conditions are maintained.

3.2.13 If a test is to be suspended for a period of time, ensures that the system is left in a safe mode.

3.2.14 Before restarting suspended test, reverifies the test prerequisites.

3.2.15 Initiates ECNs** to document required changes to the ATP.

3.2.16 Reviews recorded data, discrepancies, and exceptions.

3.2.17 Obtains information or changes necessary to clear or resolve objections during the performance of the test.

3.2.18 Signs Execution Test and Approval page when test has been performed.

3.2.19 Signs Exception form when exception has been resolved.

3.2.20 Obtains required signatures on the ATP Haster prior to reproduction and distribution.

\section{:3.3 HITNESSES}

Provided by Participating Organizations. One witness shall be a ICF KH Title III acceptance inspector.

\subsubsection{Witness the tests.}

3.3.2 Review results of testing.

3.3.3 Assist the Test Director when requested.

3.3.4 Sign Execution an Test Approval page when test has been performed.

3.3.5 Sign Exception form when exception has been resolved.

\subsection{RECORDER}

3.4.1 Prepares Field copy from the ATP Master.

3.4.2 Records names of designated personnel on Field copy of ATP prior to start of testing. 
KEH-5368(KO26) REV. 0

3.4.3 Records test instrument identification numbers and calibration expiration dates.

3.4.4 Initials and dates each test step on the field copy as it is completed, next to the step number, or on a data sheet when provided. Records Test Data. On data sheets where there is not room for both the initial and date, date may be entered at bottom of column.

3.4.5 Records objections and exceptions on an Exception form. Transfers information in ink or type to an Exception form master. Uses additional Exception forms as needed.

3.4.6 Signs Execution and Test Approval page when test has been performed.

3.4.7 After test is finished, assigns alpha numeric page numbers to added data sheets and Exception forms. Records page numbers in the Table of Contents.

3.4.8 Transfers changes and the final test results with Recorder's signature and dates for each step to the Master ink or type. Submits the completed Master to the Test Director for approval signature routing. Transmits the Field copy to ICF $K H$ when test has been accepted and exceptions closed-out.

3.4.9 Signs Exception form when exception has been resolved, and transmits to Test Director.

\subsection{TEST OPERATOR}

3.5.1 Performs tests under direction of the Test director.

3.5.2 Provides labor, equipment, and test instruments required for performing tests which have not been designated as being provided by others.

3.5.3 Requests in writing from ICF KH those services, materials, or equipment that have been designated as being supplied by others.

3.5.4 Confirms that equipment required for performing test will be available at the start of testing.

3.5.5 Signs the Execution and Test approval page. 
KEH-5368(K026) REV. 0

\subsection{CHANGE CONTROL}

Required changes to this ATP must be processed on ECNs** in accordance with company procedures. If a need for change is discovered in the course of running the test, the test shall be stopped until the ECN is approved. However, this does not prevent the running of another portion of the test unaffected by the change.

\subsection{EXECUTION}

\subsection{OCCUPATIONAL SAFETY AND HEALTH}

Individuals shall carry out their assigned work in a safe manner to protect themselves and others from undue hazards and to prevent damage to property and environment. Facility line managers shall assure the safety of activities within their areas to prevent injury, property damage, or interruption of operations. Performance of test activities shall always include safety and health aspects.

\subsection{PERFORMANCE}

5.2.1 Use ICF KH approved copy of this ATP.

5.2.2. Conduct test meeting responsibility requirements of section 3 of this ATP.

5.2.3 Perform test in accordance with steps in Section(s) 8 (9, etc) of the ATP.

5.2.4 When test has been completed, obtain signatures of test executioners and witnesses.

5.2.5 Submit the test report to ICF KH for approval.

NOTE 1: At this point, the "procedure" becomes a "report".

NOTE 2: There may be exceptions outstanding.

5.2.6 Clear exceptions and submit to ICF KH for approval. NOTE: Ideally, the cleared exceptions would be submitted with the report. Coordinate with ICF $\mathrm{KH}$ as to allowable delay between test completion and submittals. 
KEH-5368 (W026) REV. O

\subsection{EXCEPTIONS}

\subsection{GENERAL}

Exceptions to the required test results are sequentialiy numbered and recorded on individual Exception forms. This enables case-by-case resolution and approval of each exception.

Errors/exceptions in the ATP itself shall NOT be processed as test exceptions (see Section 4).

\subsection{RECORDING}

6.2.1 Number each exception sequentially as it occurs and record it on attached Exception Form.

6.2.2 Enter name and organization of objecting party for each exception.

6.2.3 Enter planned action to resolve each exception when such - determination is made.

\subsection{RETEST/RESOLUTION}

Record the action taken to resolve each exception. Action taken may not be the same as planned action.

6.3.1 When action taken results in an acceptable retest, sign and date Retest Execution and Acceptance section of the Exception form.

6.3.2 When action taken does not involve an acceptable retest, strike out the Retest Execution and Acceptance section of the Exception form.

\subsection{APPROYAL AND ACCEPTANCE}

ICF KH provides final approval and acceptance of exceptions by checking one of the following on Exception form:

6.4.1 Retest Approved and Accepted: Applicable when Retest Execution and Acceptance section is completed.

6.4.2 Exception Accepted-As-Is: Requires detailed explanation.

6.4.3 Other: Requires detailed explanation.

ICF KH signs and dates the Exception form and obtains their customer approval, as required. 
KEH-5368(KO26) REV. 0

\subsection{DISTRIBUTION}

A copy of the approved Exception form is distributed to each participant. The signed original is attached to the ATP Master.

\subsection{PREREQUISITES AND EQUIPMENT REQUIRED}

\subsection{PREREQUISITES}

All Field Tests must be successfully completed prior to execution of this ATP.

\subsection{EQUIPMENT}

The following equipment is required to complete this ATP:

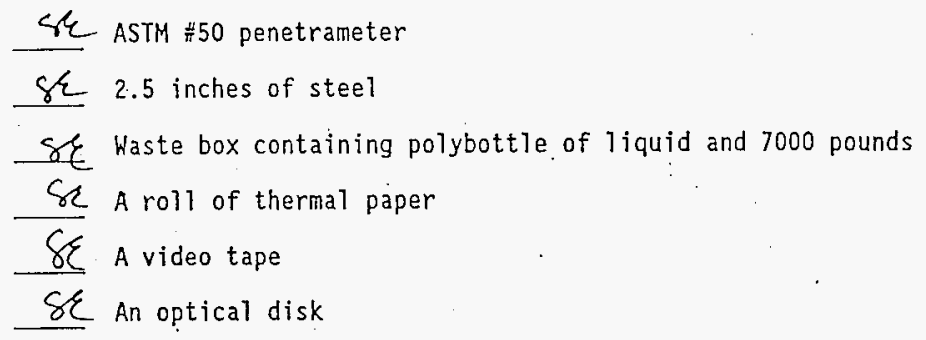

\subsection{PLANT CONTROL SYSTEM (PCS) INTERFACE}

The Box NDE System receives five inputs from and sends eight outputs to the WRAP I PCS computer. The dry contact terminations are shown on drawings J2348, sheets 2 and 3.

epeaption 001

Verify the dry contacts operate as designed; record results in Table 8.0

\subsection{BOX LOAD AND UNLOAD}

The system is designed to handle up to a 7000 pound box.

The total available time to load a box on the assembiy, scan all points of interest, unload the box and turn it around, reload the box, scan all points of interest, carry out any system checks and return comments to the data management system shall be 45 minutes or less on average. The average scan time is 10 minutes per side, leaving 25 minutes for forklift, vault door and conveyor operations. 


\section{KEH-5368(W026) REY. 0}

$8 \varepsilon$ Use forklift and NDE System to simulate examining a waste
box containing 7000 pounds into the Box NDE vault.
Record the transit times in Table 9.0

\subsection{MANIPULATORS AND CONVEYORS}

The system is designed to handle up to a 7000 pound box. The system has a "shake" button which can be used to "jog" a box to detect free liquids.

The system raises and lowers the image intensifier (I.I.) and $x$-ray tube. The system encodes the positions of the following devices: $x$-ray generator height, I.I. height, X-ray generator/I.I. lateral position. These positions are encoded within a tolerance of 0.250 inches and are displayed on the examination monitor (switchable on or off) at the remote console in the central control room.

A means is provided to remove the height synchronization and independently raise and lower the X-ray generator and image intensifier in order to permit oblique viewing.

A "joystick" type controller shall be provided for the manipulator motion controls.

SE Load a box containing 7000 pounds and a poly bottle of water into the Box NDE vault.

8 Raise and lower the I.I. and the $x$-ray tube.

$\leqslant \varepsilon$ Verify that the $x$-ray generator height can be displayed/not displayed

$8 \varepsilon$ Verify that the I.I. height can be displayed/not displayed

$S \mathcal{E}$ Verify that the $x$-ray generator/I.I. Iateral position can be displayed/not displayed

8 Verify that the entire height of the box may be viewed Se Shake the box

$S E$ Verify that the water in the bottle can be seen to slosh

\subsection{IMAGE CHAIN}

The resolution and penetration of the examination system shail be assessed using the ASTM penetrameter in accordance with ASTM-E-94. The acceptance criterium for the I.I. is the visibility of an ASTM penetrameter of 2-2T 


\section{KEH-5368(H026) REV. 0}

sensitivity through a steel thickness of 2.5 inches on the live video monitor (no image processing or enhancement).

$S\{$ place a $\# 50$ penetrameter behind 2.5 inches of steel; verify that the $2 T$ hole is visible on the monitor

\subsection{DATA STORAGE AND RETRIEVAL}

\subsection{VIDEO CASSETTE RECORDER (VCR)}

The I.I. images can be stored on video cassette using the VCR in the control room. The data links from the position encoder record the position data on the VCR. The microphone can be used to record commentary on the video cassette as well.

\subsection{OPTICAL DISK}

The I.I. images can be stored on optical disk in the control room.

\subsection{PRINTER}

The.I.I. images can be printed onto paper in the control room.

Se Manually load a box into the vault

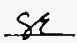

Record an I:I. image with audio commentary using the VCR

$8 E$ Play back the recording

SE Write an I.I. image to an optical disk.

SE Read the file back from the optical disk.

$8 \varepsilon$ Print an I.I. image

\subsection{MAINTENANCE ACCESSIBILITY}

The system was designed to provide access to system components for maintenance purposes. Lighting is provided inside the vault to facilitate maintenance. A manual means to open and close the vault doors in the event of motor failure is provided.

$8 \varepsilon$ Verify that equipment is accessible

$\mathcal{E}$ Verify that there is sufficient lighting inside the vault

Sf Verify that the door can be opened and closed manually 
KEH-5368(H026) REV. 0

TABLE 8.0 PLANT CONTROL SYSTEM (PCS) INTERFACE

\begin{tabular}{|c|c|c|}
\hline & SIGNAL & VERIFIED \\
\hline \multirow{5}{*}{$\begin{array}{l}\text { Facility PCS } \\
\text { to NDE System }\end{array}$} & ready to send box & $S \varepsilon$ \\
\hline & Box out; Stop Internal Conveyor & - \\
\hline & Abort Examination & $\longrightarrow$ \\
\hline & "Closed vault door" enabled & $=$ \\
\hline & ready to receive box & - \\
\hline \multirow{8}{*}{$\begin{array}{l}\text { NDE system } \\
\text { to Facility PCS }\end{array}$} & ready to receive box & $S E$ \\
\hline & start box conveyor & - \\
\hline & box in NDE vaurt & - \\
\hline & request enable to close vault door & - \\
\hline & Examination in progress & - \\
\hline & Box NDE Instrument Fault; Examination aborted & $?$ \\
\hline & $\begin{array}{l}\text { Box NDE Instrument Fault; Examination } \\
\text { continuing }\end{array}$ & $?$ \\
\hline & Box Examination Complete & - \\
\hline
\end{tabular}

exception 001 
KEH-5368(HO26) REY. O

\section{TABLE 8.0 PLANT CONTROL SYSTEM (PCS) INTERFACE}

\begin{tabular}{|c|c|c|}
\hline & SIGNAL & VERIFIED \\
\hline \multirow{5}{*}{$\begin{array}{l}\text { Facility PCS } \\
\text { to HDE system }\end{array}$} & ready to send box & XCA \\
\hline & Box out; Stop Internal Conveyor & thitt \\
\hline & Abort Examination & $\lambda \not h \not$ \\
\hline & "Closed vault door" enabled & XCA \\
\hline & ready to receive box & ThA \\
\hline \multirow{8}{*}{$\begin{array}{l}\text { NDE System } \\
\text { to Facility PCS }\end{array}$} & ready to receive box & 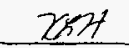 \\
\hline & start box conveyor & thit \\
\hline & box in NDE vault & XnAt \\
\hline & request enable to close vault door & ThPt \\
\hline & Examination in progress & 2814 \\
\hline & 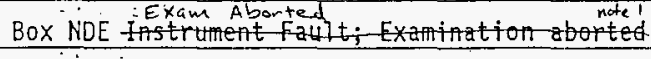 & LPPH \\
\hline & $\begin{array}{l}\text { Box- NOE Instrument Fault; Examtination note. } \\
\text { continuing }\end{array}$ & \\
\hline & Box Examination Complete & XYH \\
\hline
\end{tabular}

note. 1 - deleted firm test per. RFI 5368-005. WhIt. 
KEH-5368(WO26) REV. 0

TABLE 9.0 BOX LOAD AND UNLOAD

\begin{tabular}{|c|c|}
\hline $\begin{aligned} A= & \text { Recorded time for forklift operator } \\
& \text { to load box onto external conveyor. }\end{aligned}$ & $01: 26$ \\
\hline $\begin{aligned} B= & \text { Recorded time for Box NDE System to } \\
& \text { load box into vault, close door, open } \\
& \text { door, and unload vault to external } \\
& \text { conveyor. }\end{aligned}$ & $02: 33$ \\
\hline $\begin{aligned} C= & \text { Record time for forklift operator to } \\
& \text { unload box from external conveyor. }\end{aligned}$ & $01: 43$ \\
\hline $\begin{array}{l}D^{\prime}=2(A)+2(B)+2(C) \\
D \text { must be less than } 25 \text { minutes. }\end{array}$ & $\begin{aligned} D & =2(01: 26)+2(02: 33)+2(01: 43) \\
D & =2: 52+5: 06+3: 26 \\
& =11: 24<25: 00\end{aligned}$ \\
\hline
\end{tabular}


HNF-SD-W026-ATR-018, Rev. 0 Page 18

KEH-5368(H026) REV. O

\section{EXCEPTION SHEET}

Exception Number:

Oate:

Exception:

Planned Aetion:

-

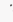

Action Taken:

Date:

Exception/Retest approval:

Retest approved

Exception

Other

and accepted

accepted as is

(Need details)

Details: 
KEH-5368(H026) REV. 0

Exception Number:
Exception (cont):
(Continuation Page)
Plarined Action (Cont):
Action Taken (Cont):




\section{KEH-5368(K026) REV. 0}

\section{EXCEPTION SHEET}

Exception Number: 001

Date: $06 / 05 / 96$

Exception: The PCS signals described in Toble 8.0 could not be completely tested as the external conveyor is not cormunicating with the PCS yet.

The signal "80x MDE Instrument Fault; Exam aborted" should be relabeled "Abort Examination" and the signa! "Box NDE Instrument Fault, Examination continuing" should be deleted. There is no need for NDE equipment to initiate either of these actions. The NDE equipment will shut itself down so that no $x$-rays can be generated if any of the safety interlock circuits are triggered. The radiographer will manually signal the PCS if an exam is aborted and will verbally inform the Dos of the reason.

Planied Action: Retest the PCS signats described in Table 8.0 when the external conveyor circuitry is complete. Submit on RFI to ICF-XH to change the signal labels as described above.

Action raken:

RFI \#5368-005 wAS SUBMITTEO 8/30/96.

Date: $9 / 5 / 96$ PCS SIGNALS WERE SATISFACTORILY RETESTED.

Exception/Retest approval:

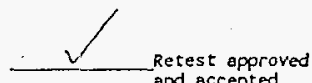

Retest approved

Exception

occepted as is

other

(Keed details)

Details:

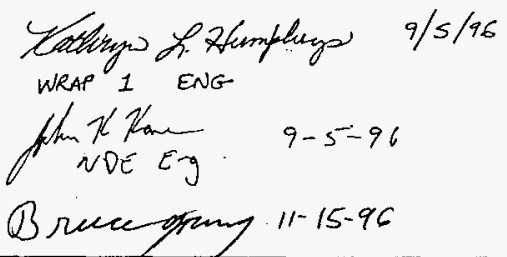




$$
\text { HNF-SD-W026-ATR-018, Rev. } 0 \text { Page } 21
$$

RECEIVED

- ATTÁCHMEHT A.l

$$
\text { KEH-5366 }
$$

"SITE, FACILITY AHO PROCESS SYSTEKS* PROJECT $\mathrm{X}-025$ REQUEST FOR IKFORMATIOK (RFI)
AUG 301996

ICF KH WRAP 1

PART I: DESCRIBTIOH OF REQUEST

RFI Short THile Bor NDE PCS Communications

Response Dus Dete Dr:g/SpeC Rei._13533 RFI Ho. $5368-005$ Requesting Organization V.J. TECHNCLCGES, iNe.

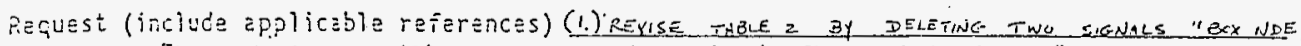

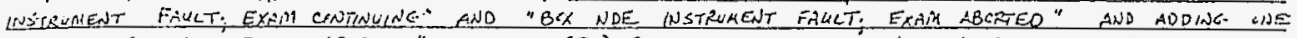
SIGTAC "BXX NDE EXAM ABXRTED."

(2.) REYSE TABLE 3 BY CANAENG STEP 23 TC READ:

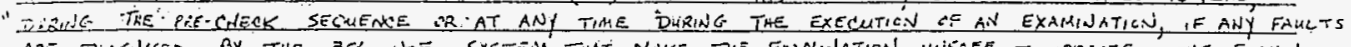

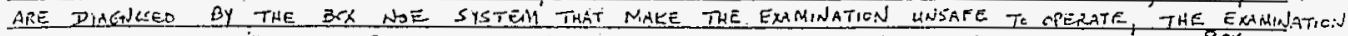

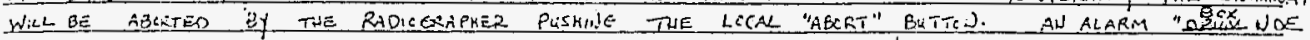

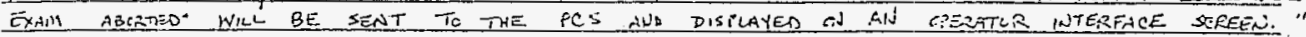

Originatcr

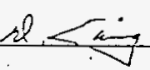
$D=\div \geq 8 / 30 / 96$

PART II: RESPGHSE TO REQUEST

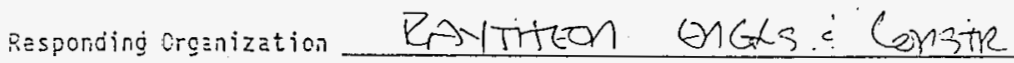

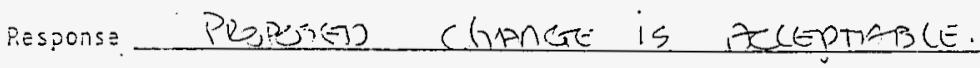

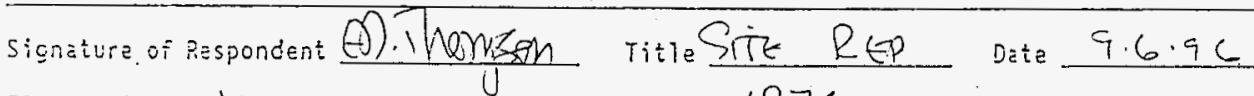

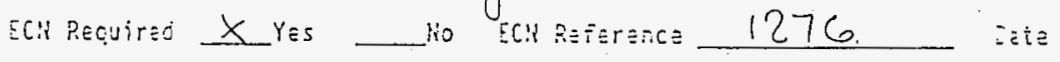

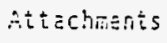

Distribution Dates:

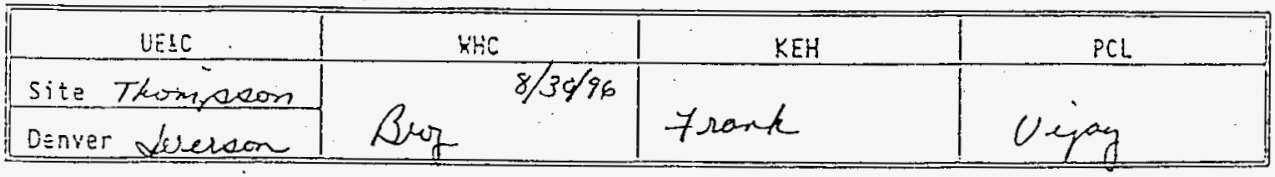




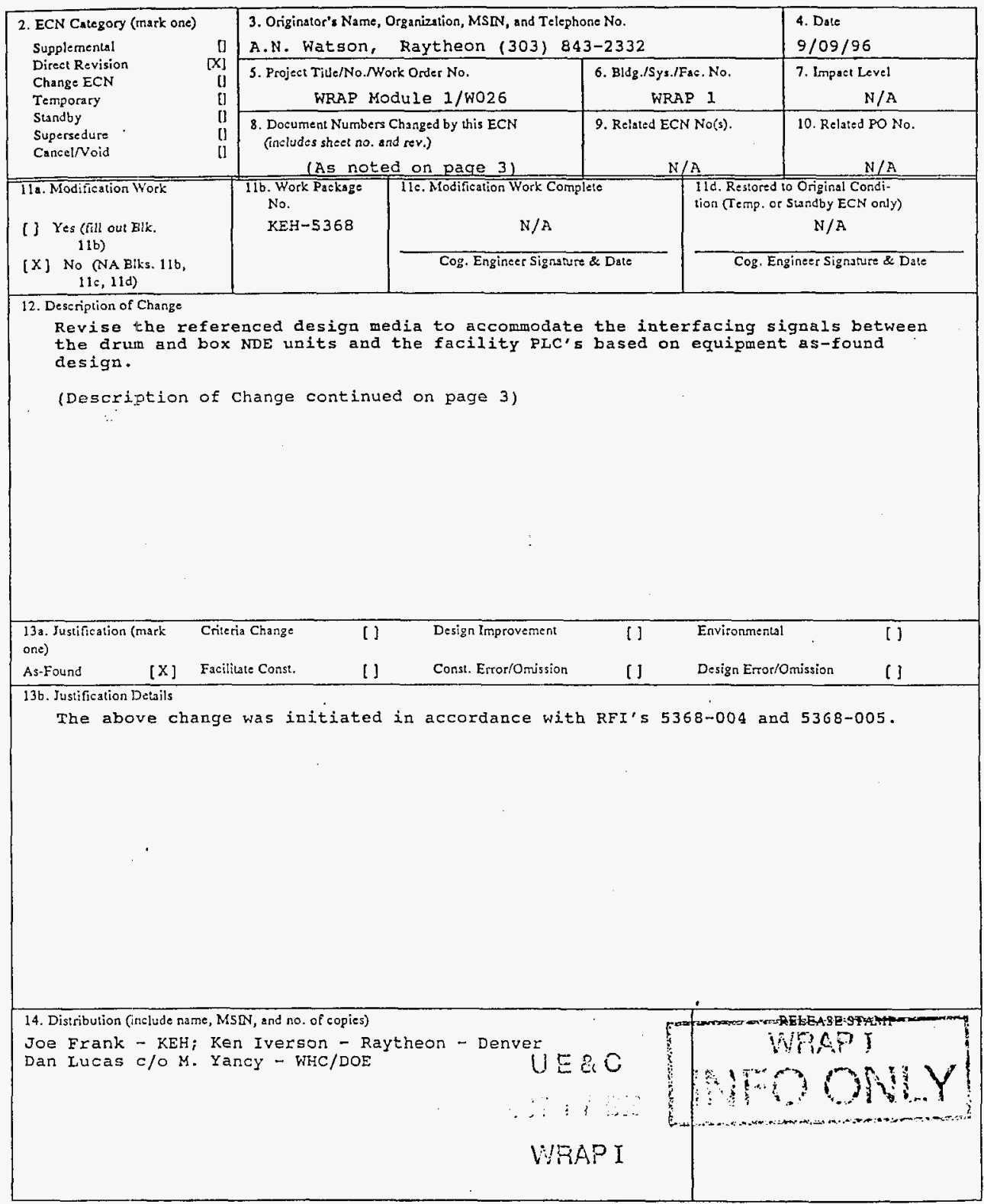




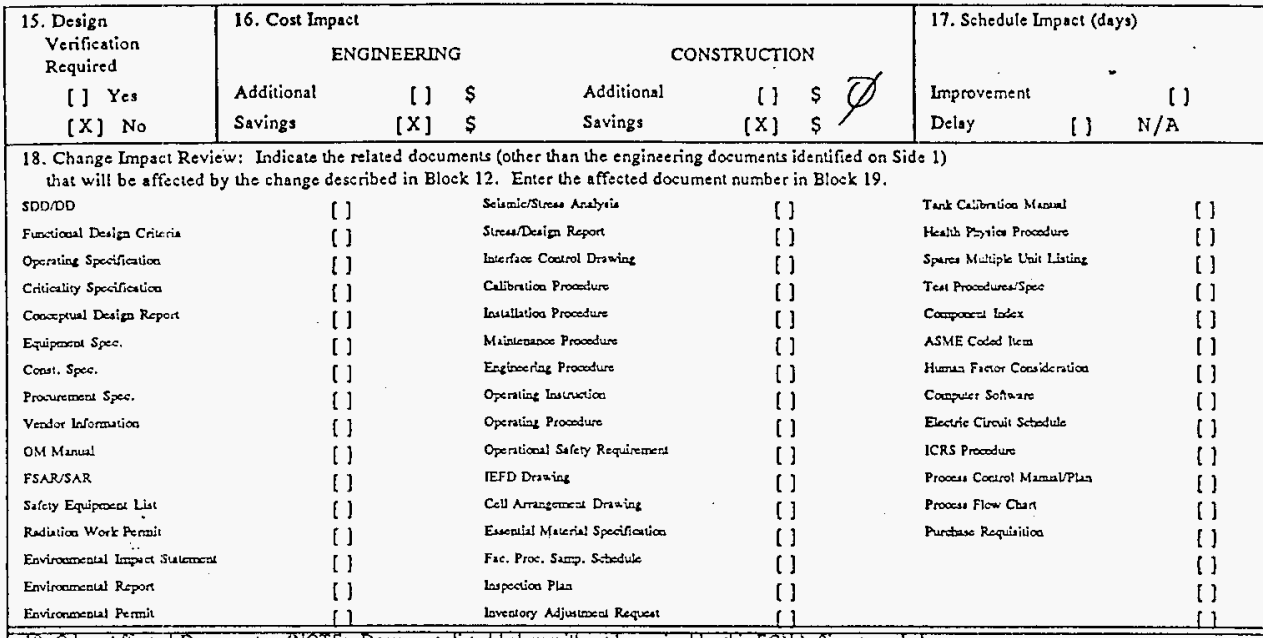

19. Other Affected Documents: (NOTE: Documenis listed below will not be revised by this ECN.) Signatures below indicate that the signing organization has been notified of other affected documents listed below.

20. Approvals

Signature

OPERATIONS AND ENGINEERING

Cog./Project Engineer DR BROz

Cog./Project Engr. Mgr. DR LUCAS

QA J MCGEE

Safely

Security

Proj. Prog./Dept. Mgr.

Def. React. Div.

Chern. Proc. Div.

Def. Wst. Mgmt. Div.

Adv. React. Dev. Div.

Proj. Dept.

Environ. Div.

IRM Dept.

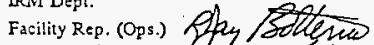

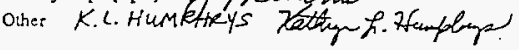

Date

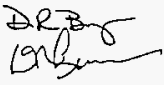

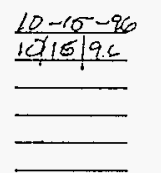
ARCHITECT-ENGNEER

PE

QA

Salety

Design

Other

DORSEY THOMPSON

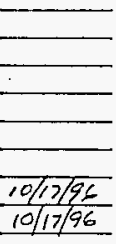

Site Representative

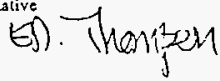

DEPARTMENT OF ENERGY

ADDTIONAL
Signature

Dale

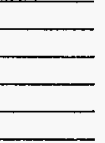

9.27 .96 


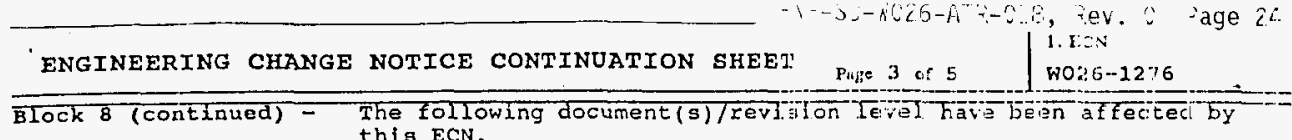
this ECN.

The following is a list of drawings and specifications that are lmpacted by this change notice.

\section{Affected Documents:}

Specification sections:

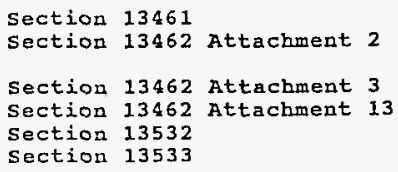

\author{
Plant Management System Hardware \\ Plant Management system Software - NDE/NDA Internal \\ transport \\ Plant Management system Software - Drum NDE \\ Plant Management system Software - Box NDE \\ Drum Non-destructive examination system \\ Box Non-destructive examination system
}

Block 12 (continued) -

The following is a list of documents (drawings with new revision level, sketches with rev No: and change requirements to specifications) which are being issued with this ECN .

\section{Specification sections}

Section 13461 Plant Management System Hardware (Specification not re-issued with this ECN).

1. Apperdix B Instrument I/O list.

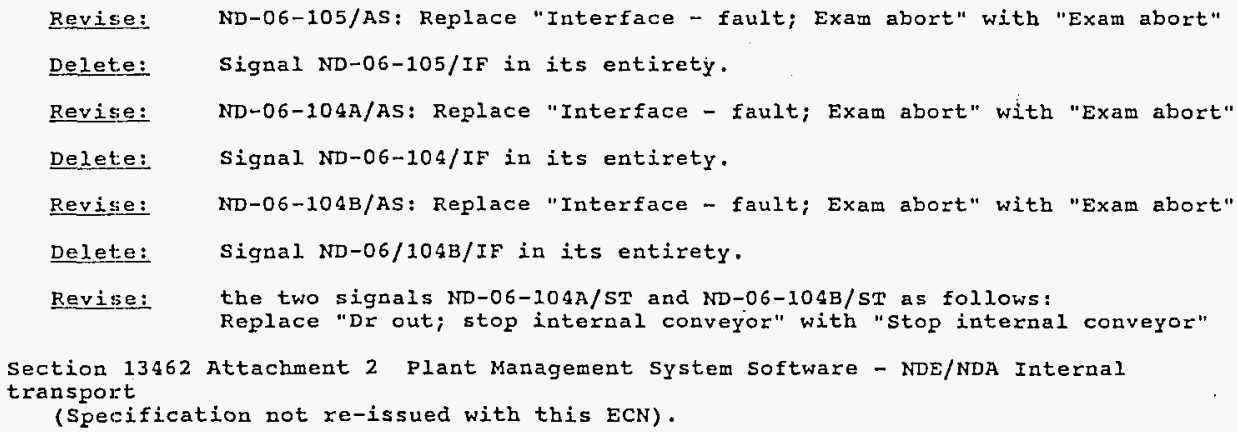

2. Table 2.2

Revise: the two signals ND-06-104A/ST and ND-06-104B/ST as follows: Replace "Transfer failure; stop internal conveyor" witb "stop internal conveyor"

3. Table 2.3, Drum Transfer from NDE station, step 7

Revise: Replace "...signals the NDE that "drum out; stop internal conveyor" with "...signals the NDE "stop internal conveyor".

Section 13462 Attachment 3 Plant Management System Software - Drum NDE

(Specification not re-issued with this $E C N$ ). 
4. Table 3.1

Delete: Whole row of sigaal "Drum NDE fault ; examination continuing"

Revise: Replace: "Drum NDE Instrument fault; Examination aborted" with "Drum NDE exam aborted".

5. Table 3.3 , step 9

Revise: Replace the whole step to read:

"During the pre-check sequence or at any time during the execution of an exam, if any faults are diagnosed by the Drum NDE system that make it unsafe to operate, the examination will be aborted by tbe NDE system, sbutting itself down. The NDE system will switch on a light which will prompt the radiographer to push the local "Abort" button. An alarm "Drum NDE exam aborted" will be sent to the PCS and be displayed on an operator interface screen This will cause the icon color of the equipment to change to RED."

Section 13462 Attachment 13 Plant Management System Software - Box NDE

(Specification not re-issued with this ECN).

6. Table 13.1

Delete: Whole row of signal "Box NDE fault ; examination continuing"

Revise: Replace: "Box NDE Instrument fault; Examination aborted" with "Box NDE exam aborted".

7. Table 13.3 , step 25

Revise: Replace the whole step to read:

"During the pre-check sequence or at any time during the execution of an exam, if any faults are diagnosed by the Box NDE system that make it unsafe to operate, the examination will be aborted by the NDE system, shutting itself down. The NDE system will switch on a light which will prompt the radiographer to push the local "Abort" button. An alarm "Box NDE exam aborted" will be sent to the PCS and be displayed op an operator interface screen This will cause the icon color of the equipment to change to RED."

Section 13532 Drum Non-destructive examination system (Specification not re-issued with this $E C N$ ).

8. Table 2:

Delete: the signal "Drum NDE Instrument fault; Examination continuing"

Revise: Replace "Drum NDE Instrument fault; Examination aborted" with "Drum NDE exam aborted"

Revise: the two signals ND-06-104A/ST and ND-06-104B/ST as follows: Replace "Transfer failure; stop internal conveyor" with "stop internal conveyor"

9. Table 3, step 21:

Revise: Replace the whole step to read:

"During the pre-check sequence or at any time during the execution of an exam, if any faults are diagnosed by the Drum NDE system that make it unsafe to operate, the examination will be aborted by the NDE system shutting itself down. The NDE system will switch on a light which will prompt the radiographer to push the local "Abort" button. An alarm "Drum NDE exam aborted" will be sent to the pCs and be displayed on an operator interface screen." 


\section{ENGINEERING CHANGE NOTICE CONTINUATION SHEET}

10. Table 3, step 27:

Revise: Replace "Drur out; stop internal conveyor" witt "stop internal conveyor".

11. Table 3, step 29:

Revise: "Transfer failure; stop internal conveyor" wita "stop internal conveyor".

Section 13533 Box Non-destructive examination system

(specification not re-issued with this $E C N$ ).

12. Table 2:

Delete: the signal "Box NDE Instrument fault; Examinatjon continuing"

Revise: Replace "Box NDE Instrument fault; Examination aborted" with "Drum NDE exam aborted"

13. Table 3, step 23:

Revise: Replace the whole step to read:

"During the pre-check sequence or at any time during the execution of an exam, if any faults are diagnosed by the Box NDE system that make it unsafe to operate, the examination will be aborted by the NDE system, shutting itself down. The NDE system will switch on a light which will prompt the radiographer to push the local "Abort" button. An alarm "Box NDE exam aborted" will be sent to the PCS and be displayed on an operator interface screen." 
THIS PAGE INTENTIONALLY LEFT BLANK 